\title{
RESULTS OF DEEP-WELL INJECTION TESTING AT MULBERRY, FLORIDA
}

U.S. GEOLOGICAL SURVEY

WATER-RESOURCES INVESTIGATIONS 81-75

Prepared in cooperation with the

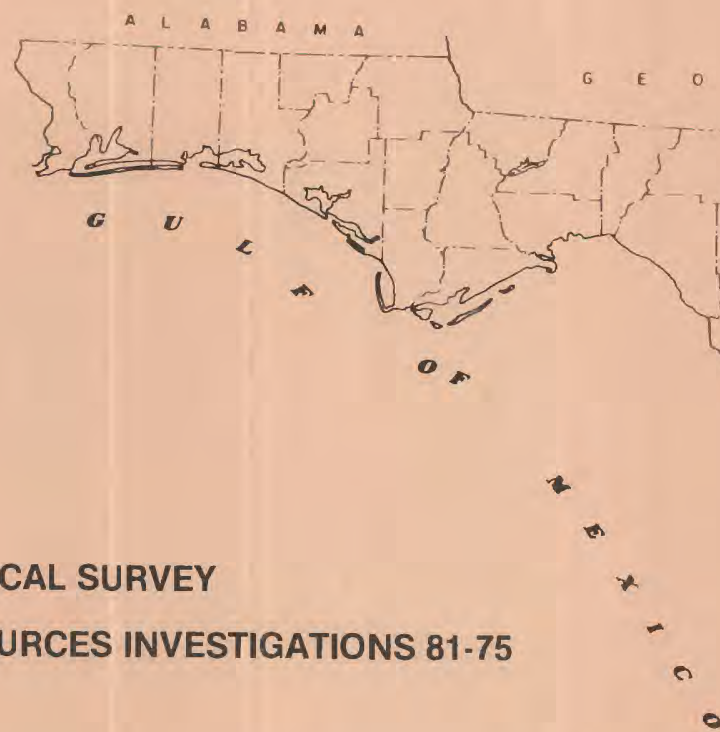

FLORIDA DEPARTMENT OF ENVIRONMENTAL REGULATION 


\begin{tabular}{|c|c|c|}
\hline $\begin{array}{l}\text { REPORT DOCUMENTATION } \\
\text { PAGE }\end{array}$ & 1. REPORT NO. & 3. Recipient's Arcession No. \\
\hline \multirow{2}{*}{\multicolumn{2}{|c|}{$\begin{array}{l}\text { 4. Title and Subtitle } \\
\text { RESULTS OF DEEP-WELL INJECTION TESTING AT MULBERRY, FLORIDA }\end{array}$}} & $\begin{array}{l}\text { 5. Report Date } \\
\text { February } 1982\end{array}$ \\
\hline & & 6. \\
\hline $\begin{array}{l}\text { 7. Author(s) } \\
\text { John J. Hickey and Wi }\end{array}$ & 1.1.am E. Wilson & $\begin{array}{l}\text { 8. Performing Organization Rept. No. } \\
\text { USGS/WRI } 81-75\end{array}$ \\
\hline \multicolumn{2}{|c|}{$\begin{array}{l}\text { 9. Performing Organization Name and Address } \\
\text { U.S. Geological Survey, Water Resources Division } \\
325 \text { John Knox Road, Suite F- } 240 \\
\text { Tallahassee, Florida } 32303\end{array}$} & $\begin{array}{l}\text { 11. Contract(C) or Grant(G) No. } \\
\text { (C) }\end{array}$ \\
\hline \multirow{2}{*}{\multicolumn{2}{|c|}{$\begin{array}{l}\text { 12. Sponsoring Organization Name and Address } \\
\text { U.S. Geological Survey, Water Resources Division } \\
325 \text { John Knox Road, Suite F-240 } \\
\text { Tallahassee, Florida } 32303\end{array}$}} & 13. Type of Report \& Period Covered \\
\hline & & 14. \\
\hline
\end{tabular}

\section{Supplementary Notes}

Prepared in cooperation with the Florida Department of Environmental Regulation

16. Abstract (Limit: 200 words) At the Kaiser Aluminum and Chemical Corporation plant, Mulberry, Florida, high-chloride, acidic liquid wastes are injected into a dolomite section at depths below about 4,000 feet below land surface. Sonar caliper logs made in April 1976 revealed a solution chamber that is about 100 feet in height and has a maximum diameter of 23 feet in the injection zone. Results of two injection tests in 1972 were inconclusive because of complex conditions and the lack of an observation well that was open to the injection zone. In 1975, a satellite monitor well was drilled 2,291 feet from the injection well and completed open to the injection zone. In April 1975 and September 1976, a series of three injection tests were performed. Duration of the tests ranged from 240 to 10,020 minutes and injection rates ranged from 110 to 230 gallons per minute. Based on an evaluation of the factors that affect hydraulic response, water-level data suitable for interpretation of hydraulic characteristics of the injection zone were identified to occur from 200 to 1,000 minutes during the 10,020-minute test. Test results indicate that leakage through confining beds is occurring. Transmissivity of the injection zone was computed to be within the range from 700 to 1,000 feet squared per day and storage ${ }_{5}$ coefficient of the injection zone was computed to be within the range from $4 \times 10^{-5}$ to $6 \times 10^{-5}$. The confining bed accepting most of the leakage appears to be the underlying bed. Also, it appears that the overlying beds are probably relatively impermeable and significantly retard the vertical movement of neutralized waste effluent.

17. Document Analysis a. Descriptors

*Injection wells, *Transmissivity, *Industrial wastes, Aquifer characteristics, Aquitards, Carbonate rocks, Ground-water barriers, Hydrogeology, Leakage, Florida

b. Identifiers/Open-Ended Terms

Acidic waste

c. COSATI Field/Group

18. Availability Statement

No restriction on distribution

19. Security Class (This Report) UNCLASS IFIED

20. Security Class (This Page)

UNCLASSIFIED
21. No. of Pages 20 22. Price 
RESULTS OF DEEP-WELL INJECTION TESTING

AT MULBERRY, FLORIDA

By John J. Hickey and William E. Wilson

U.S. GEOLOGICAL SURVEY

Water-Resources Investigations 81-75

Prepared in cooperation with the

FLORIDA DEPARTMENT OF ENVIRONMENTAL REGULATION

Tallahassee, Florida 
UNITED STATES DEPARTMENT OF THE INTERIOR

JAMES G. WATT, Secretary

GEOLOGICAL SURVEY

Dallas L. Peck, Director

For additional information write to:

U.S. Geological Survey

325 John Knox Road, Suite F-240

Tallahassee, Florida 32303 
CONTENTS

Abstract -

Introduction - 1

Injection site -

Hydrogeology -

1972 tests - 6

1975 and 1976 tests -__ 8

Factors that complicate the interpretation of water-level data at the Kaiser site - 10

Estimated injection-zone hydraulic characteristics _-_

Discussion -

Conclusions -

References -

ILLUSTRATIONS

Page

Figure 1. Map showing location of waste-injection system, Kaiser Aluminum and Chemical Corporation, Mulberry, Florida --_--- 2

2. Diagram showing construction of injection well and satellite monitor wel1 - 4

3. Graphs showing sonar and mechanical caliper logs of injection we11, April 1976 - 6

4. Diagram showing hydrogeologic model of Kaiser injection site -- 7

5. Graph showing bottom-hole pressure during injection tests in 1975 and 1976

6. Semi-logarithmic graph showing adjusted and unadjusted waterlevel changes at satellite monitor well during injection, April 14-21, 1975 -_-_- 11

7. Logarithmic graph showing adjusted and unadjusted waterlevel changes at satellite monitor well during injection, Apri1 14-21, 1975 - 13 
Factors for converting inch-pound units to International System (SI) units and abbreviation of units

Mu1tip1y

inch (in)
foot ( $f t)$
mile (mi)

cubic foot $\left(f t^{3}\right)$

cubic $_{3}$ foot per year

( $\left.\mathrm{ft}^{3} / \mathrm{yr}\right)$

gallon per minute (gal/min)

pound per square inch $\left(1 \mathrm{~b} / \mathrm{in}^{2}\right)$

foot squared per day ( $\mathrm{ft}^{2} / \mathrm{d}$ )

foot per day per foot

[ $(\mathrm{ft} / \mathrm{d}) / \mathrm{ft}$ ]
By

To obtain

\section{Length}

2. 540

0.3048

1. 609

Volume

0.02832

Rate

0.02832

0.06309

Pressure

$6.895 \times 10^{-3}$

million Newtons per square meter $\left(\mathrm{MN} / \mathrm{m}^{2}\right)$

Transmissivity

0.09290

meter squared per day $\left(\mathrm{m}^{2} / \mathrm{d}\right)$

\section{Leakance}

1.000

meter per day per meter

$[(\mathrm{m} / \mathrm{d}) / \mathrm{m}]$ 


\title{
RESULTS OF DEEP-WELL INJECTION TESTING AT MULBERRY, FLORIDA
}

\author{
By John J. Hickey and William E. Wilson
}

ABSTRACT

At the Kaiser Aluminum and Chemical Corporation plant, Mulberry, Florida, high-chloride, acidic liquid wastes are injected into a dolomite section at depths below about 4,000 feet below land surface. Sonar caliper logs made in Apri1 1976 revealed a solution chamber that is about 100 feet in height and has a maximum diameter of 23 feet in the injection zone.

Results of two injection tests in 1972 were inconclusive because of complex conditions and the lack of an observation well that was open to the injection zone. In 1975, a satellite monitor well was drilled 2,291 feet from the injection well and completed open to the injection zone. In April 1975 and September 1976, a series of three injection tests were performed. Duration of the tests ranged from 240 to 10,020 minutes and injection rates ranged from 110 to 230 gallons per minute. Based on an evaluation of the factors that affect hydraulic response, water-level data suitable for interpretation of hydraulic characteristics of the injection zone were identified to occur from 200 to 1,000 minutes during the 10,020-minute test. Test results indicate that leakage through confining beds is occurring.

Transmissivity of the injection zone was computed to be within the range from 700 to 1,000 feet squared per day and storage coefficient of the injection zone was computed to be within the range from $4 \times 10^{-5}$ to $6 \times 10^{-5}$. The confining bed accepting most of the leakage appears to be the underlying bed. Also, it appears that the overlying beds are probably relatively impermeable and significantly retard the vertical movement of neutralized waste effluent.

\section{INTRODUCTION}

In 1972, the Kaiser Aluminum and Chemical Corporation plant at Mulberry, Fla. (fig. 1), began injecting acidic, high-chloride liquid industrial waste into a dolomite section that is more than 4,000 feet below land surface. Injection tests were conducted in the fall of 1972, prior to start of full-time injection operations, and in 1975 and 1976. The U.S. Geological Survey participated in collection and evaluation of hydrologic data during all tests, in cooperation with the Florida Department of Pollution Control and the Florida Department of Environmental Regulation. Subsequent to the tests, the Geological Survey has maintained a program of data collection at the Kaiser site. Hydrologic data collected through 1976 were reported by Wilson (1977). The investigations are part of the Geological Survey's research program to evaluate effects of underground waste injection on the nation's subsurface environment.

As reported by Wilson and others (1973), results of the 1972 injection tests were inconclusive because of limited test facilities and complex testing conditions. The purpose of this report is to present results of the 1975 and 1976 tests and to describe injection-zone characteristics. 


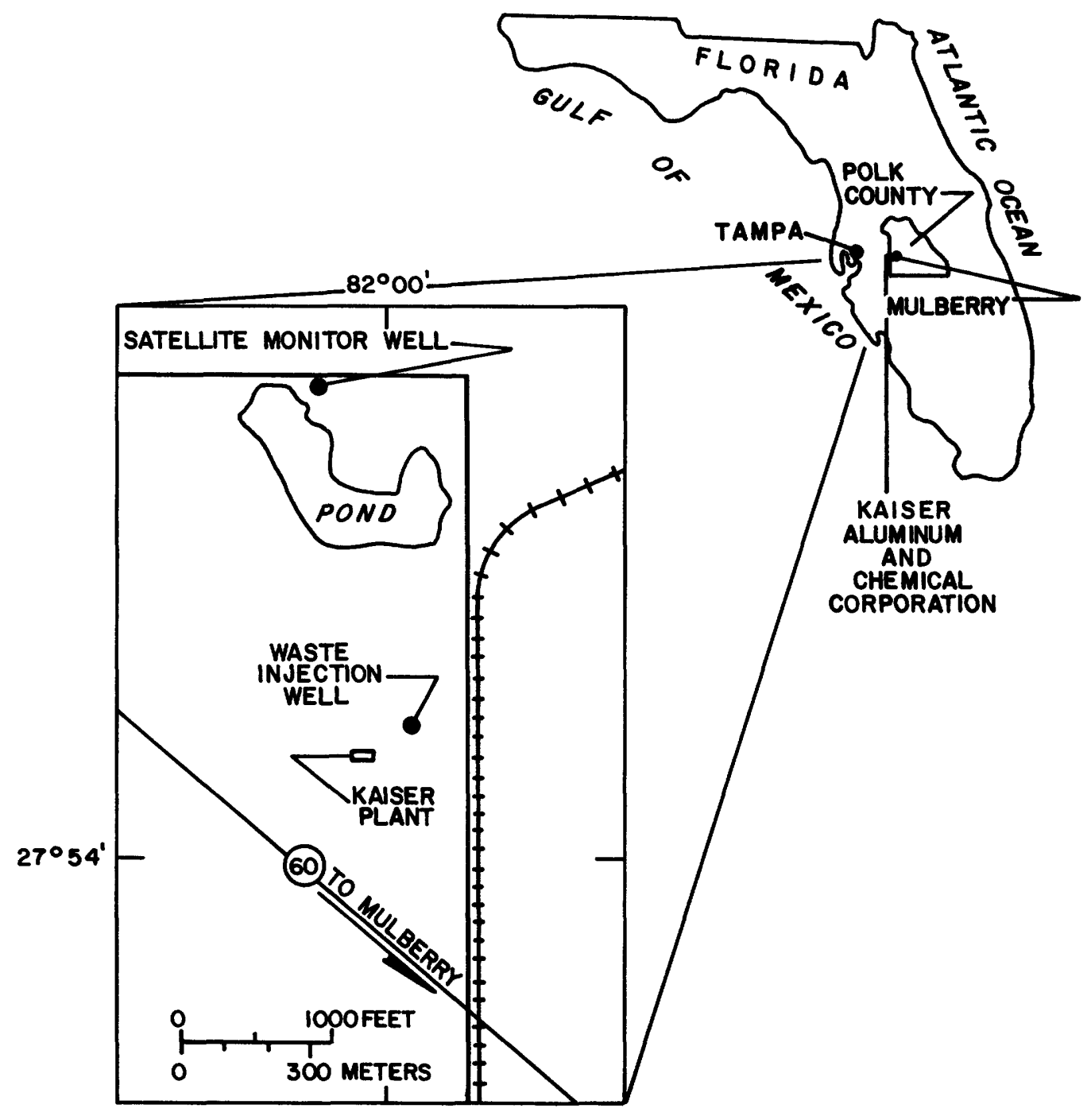

Figure 1.--Location of waste-injection system, Kaiser Aluminum and Chemical Corporation, Mulberry, Florida. 


\section{INJECTION SITE}

Details of injection facilities were reported by Wilson and others (1973). As initially constructed, the well was finished with an open hole, 9-7/8 inches in diameter, 4,040 to 4,984 feet below land surface (fig. 2).

At times of the 1972 and 1975 tests, a 4-1/2 inch open-ended fiberglass injection tubing extended 411 feet into the open hole; the bottom 30 feet of tubing was slotted. The annulus between the fiberglass injection tubing and the 7-5/8 inch casing was sealed off from the open hole by a noncorrodible packer assembly. The lower 400 feet of the 7-5/8 inch casing was composed of fiberglass-reinforced epoxy (fibercast) pipe. Two monitor tubes in the injection-wel1 annulus are open to permeable zones above the confining beds; the shallower well is perforated from 1,254 to 1,264 feet, and the deeper well is perforated from 2,775 to 2,788 feet below land surface (fig. 2).

In April 1975, a satellite monitor well was drilled 2,291 feet from the injection well. The monitor well is cased and grouted to 4,016 feet below the land surface and finished open hole from 4,016 to 5,000 feet (fig 2).

In April 1976, the injection well was reworked to repair a leak in the casing. During the workover, the lower fibercast part of the 7-5/8 inch casing, the packer bore receptacle, and a fibercast collar were lost down the hole. In the modified well, open hole begins at 3,992 feet. The steel casing was regrouted above 3,992 feet, and a packer was installed about 100 feet above the bottom of the casing between the injection tube and the casing. The 4-1/2 inch injection tube, with the lower 27 feet slotted, extends to 4,333 feet. Diesel oil was emplaced in the annulus below the packer and into the upper part of the open hole to protect the lower part of the well from injected acid waste.

From 1972 through September 1976, about 317 Mgal of effluent was injected at the Kaiser plant. During this period, a cavity developed in the open-hole section of the injection we11, as revealed by a series of sonar and mechanical caliper logs. Logs were run in 1972, April 1975, Apri1 1976, and September 1976; the sonar logs were evaluated by Shannon and Wilson, Inc. (1976, 1977).

In April 1975, the cavity averaged about 8.4 feet in diameter in the depth interval 4,358 to 4,458 feet (J. T. Sargent, written commun., 1977). Figure 3 shows sonar and mechanical logs for April 1976, at which time maximum diameter was 23 feet and estimated cavity volyme was $20,100 \mathrm{ft}^{3}$. By September 1976, cavity volume had exceeded $30,000 \mathrm{ft}^{3}$.

Estimated rate of discrete cavity growth was $18,000 \mathrm{ft}^{3} / \mathrm{yr}$ during April 1975 to September 1976 (Shannon and Wilson, Inc., 1977). Prior to 1975, average annual growth rate was much less (about 2,500 $\mathrm{ft}^{3} / \mathrm{yr}$ ). Shannon and Wilson, Inc. (1977) postulated that much of the early solution activity was utilized in developing a zone of increased porosity in rocks surrounding the borehole.

Development of a zone of increased porosity was inferred from calculations involving the volume of waste injected and presumed reaction rates with the rock (Shannon and Wilson, Inc., 1976). Calculations show that more solution has probably occurred than can be accounted for by the discrete cavity alone. The zone of increased porosity was estimated to extend about 70 feet beyond the cavity in 1976 (Shannon and Wilson, Inc., 1976), and its thickness was probably slightly less than that during the 1975 tests. 


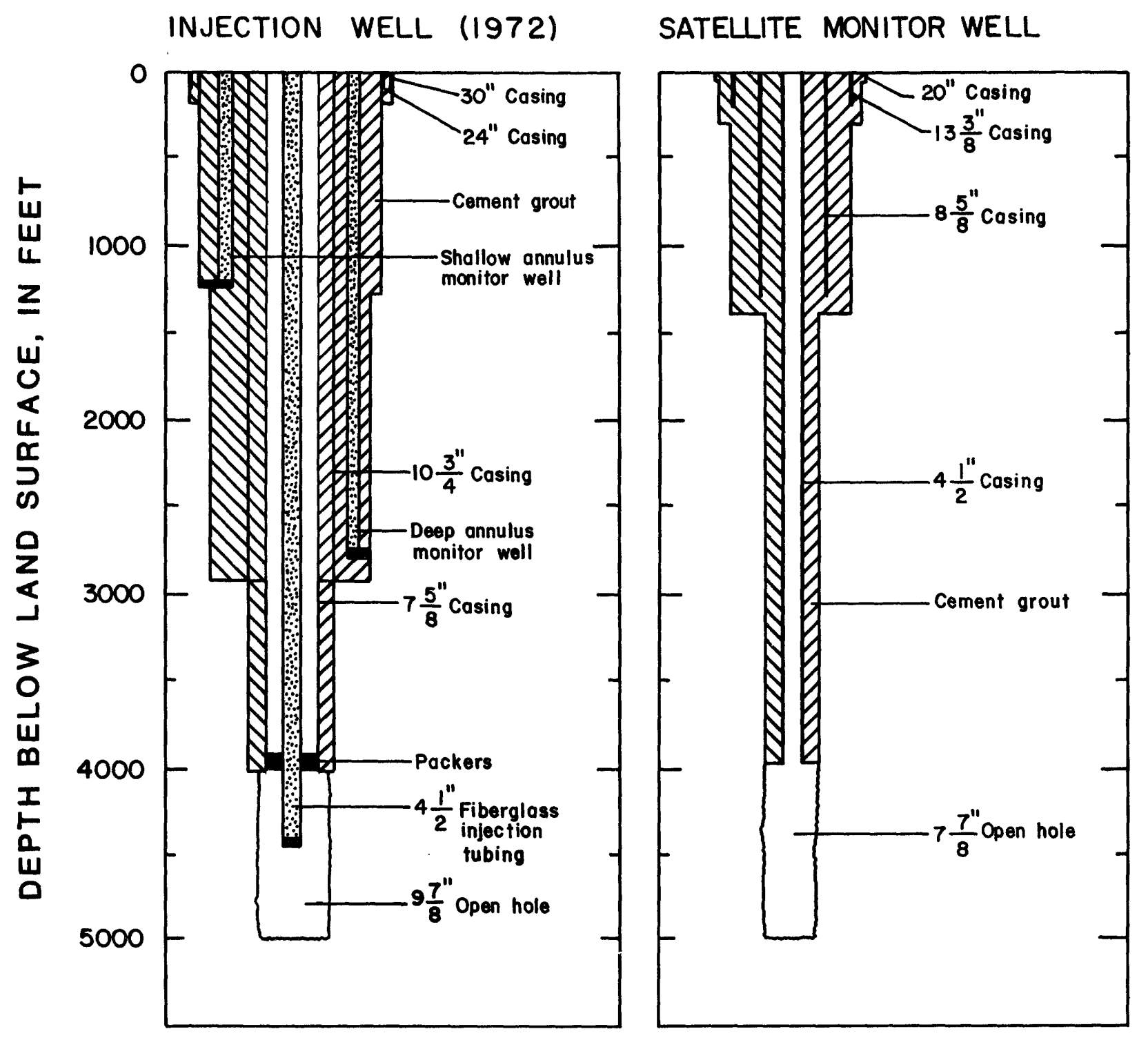

Figure 2.--Construction of injection well and satellite monitor well. 
During the mechanical caliper logging in April 1976, the logging tool penetrated sediment in the borehole at about 4,450 feet, and the tool could not be lowered below about 4,490 feet. As suggested by material adhering to the tool upon retrieval, the sediment is probably insoluble residue that settled into the open hole as overlying rocks were dissolved. The material is assumed to fill the open hole below about 4,450 feet, and presumably similar conditions existed during the tests in 1975.

\section{HYDROGEOLOGY}

Hydrogeologic conditions at the injection site were reported by Wilson and others (1973). The injection well penetrates nearly 5,000 feet of sedimentary rock composed principally of limestone and dolomite ranging in age from Late Cretaceous to Holocene. The open-hole section, 4,040 to 4,984 feet below land surface (fig. 2), consists of the lower part of the Cedar Keys Limestone of Paleocene age and the underlying Lawson Limestone of Late Cretaceous age and beds of Tayloran Age. Tracer tests in 1972 indicated that the most permeable interval of this open-hole section is near the base of the lower part of the Cedar Keys Limestone from about 4,100 to 4,510 feet below land surface with the highest permeability from about 4,340 to 4,510 feet. Subsequent data collected at the site (fig. 3) support this interpretation. Directly overlying the openhole section, in the middle part of the Cedar Keys Limestone, is a sequence of alternating beds of anhydrite and dolomite.

Figure 4 shows the hydrogeologic model used in this report. The alternating beds of anhydrite and dolomite overlying the injection zone are grouped together into the upper confining bed. This definition is based principally upon the geologic inference that the anhydrite beds would have very low permeability and thus cause the equivalent permeability of the sequence to be very low. Thickness of the alternating beds of anhydrite and dolomite is 780 feet (Wilson and others, 1973).

The limestone bed underlying the injection zone is defined as the lower confining bed. This confining bed is probably more permeable than the upper confining bed, as suggested by laboratory analyses of sidewall cores (Wilson and others, 1973; unpublished data, Kaiser Aluminum, 1976). Thickness of the limestone bed at this site is not known because drilling was terminated after penetrating the bed about 480 feet. However, correlation of geophysical logs with logs from a deep oil test well in Pinellas County, about 60 miles west of the site, suggest that the limestone bed's thickness could be in the order of 2,000 feet and that it is underlain by a clay.

The injection zone is composed of dolomite and is about 410 feet thick. It is subdivided into two parts with the upper part less permeable than the lower part. The upper part of the injection zone is about 240 feet thick and the lower part is about 170 feet thick.

The hydrogeologic model used in this report is applicable to the interpretation of the hydraulic behavior of both native formation water and neutralized waste in the injection zone. The model is not applicable to the interpretation of the chemical behavior of the acidic waste prior to neutralization in the vicinity of the injection well where parts of both the injection zone and upper confining bed have been dissolved (fig. 3 ). 


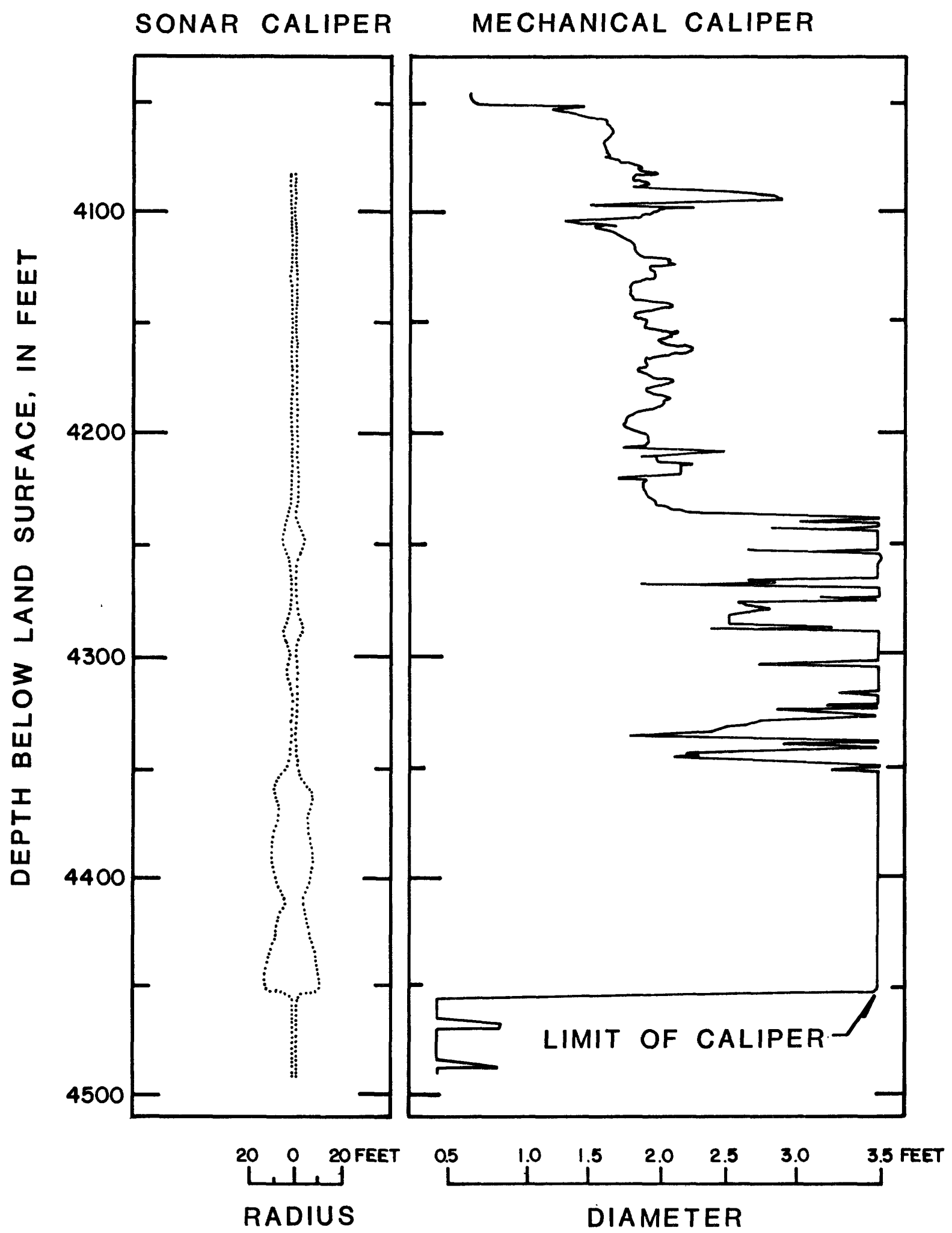

Figure 3.--Sonar and mechanical caliper logs of injection well, April 1976. 


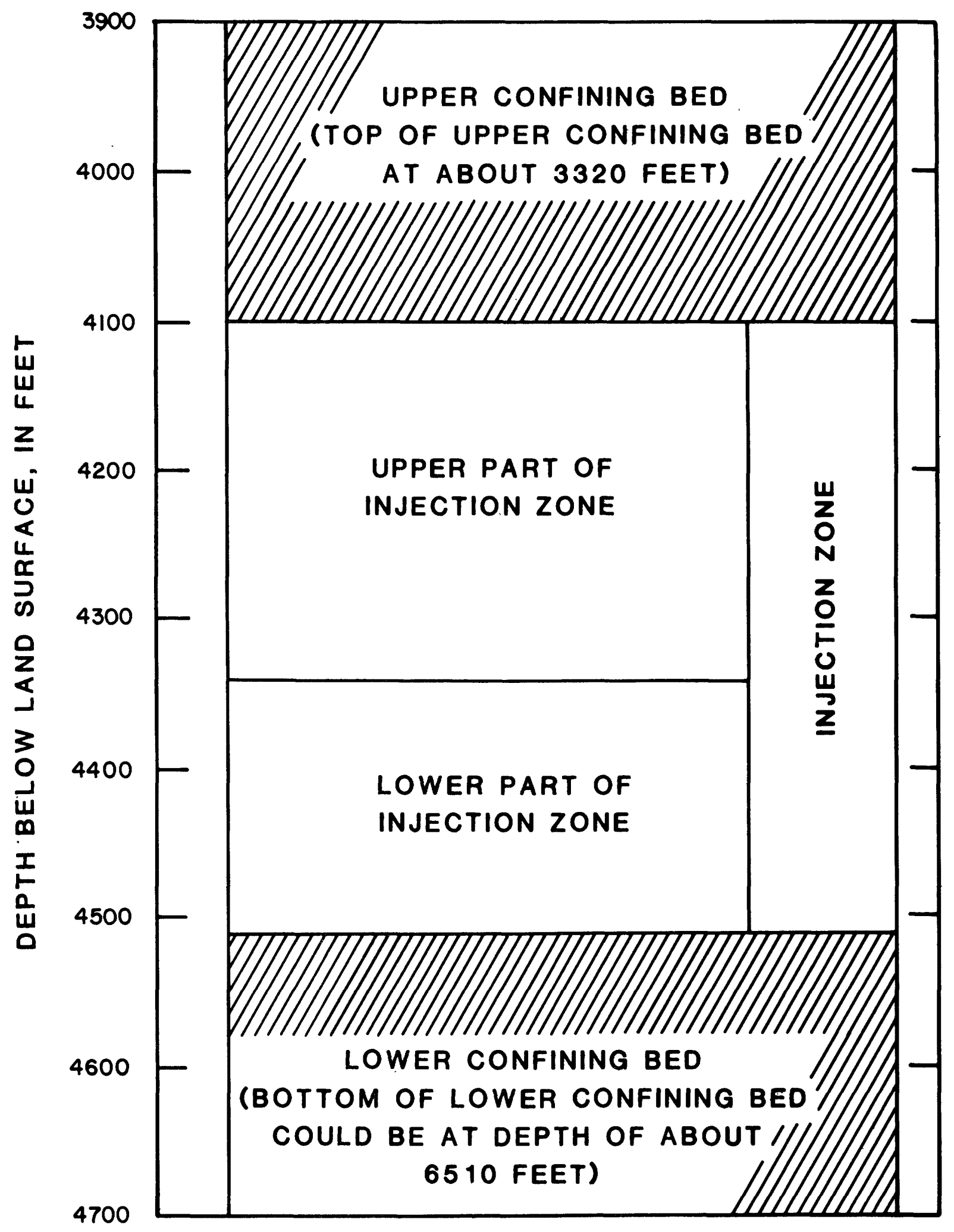

Figure 4.--Hydrogeologic model of Kaiser injection site. 
1972 TESTS

Two tests were conducted on the injection well in the fall of 1972 (Wilson and others, 1973). During injection of acidic waste, pressure at the well head and water levels in the two annulus monitor wells were observed, and decline in fluid level in the injection well was measured after injection ceased. Results of the first test indicated that transmissivity of the injection zone was probably less than $800 \mathrm{ft} / \mathrm{d}$ and may have been as small as $400 \mathrm{ft}^{2} / \mathrm{d}$; transmissivity computed from the second test was $2,000 \mathrm{ft}^{2} / \mathrm{d}$ (Wilson and others, 1973, p. 558).

Limited test facilities and complex test conditions complicated analysis of the 1972 test results. The tests were inadequate to determine reliable hydraulic characteristics of the injection zone or leakage characteristics of confining beds. Estimate of leakage through confining beds was not made. The tests emphasized the desirability of including at least one observation well open to the same zone as the injection well and of measuring bottom-hole pressure in the injection well during tests. The satellite monitor well and the 1975 tests were designed to satisfy these conditions as much as possible.

\section{AND 1976 TESTS}

Two injection tests were run in April 1975. In the first, called the bottom-hole pressure test, bottom-hole pressure was recorded with an electronic gage set at 4,450 feet below land surface, near the bottom of the injection tubing. Static bottom-hole pressure was $1,961 \mathrm{lb} / \mathrm{in}^{2}$ when the water level in the injection well was at 60 feet below land surface. Acidic waste, having a density of $1.047 \mathrm{gm} / \mathrm{mL}$ and a pH of less than 1.0 , was injected at an initial rate of $185 \mathrm{gal} / \mathrm{min}$. Well-head pressure was not observed at this injection rate because the water level in the well remained below the well head. At $820 \mathrm{~min}$, the injegtion rate was increased to about $285 \mathrm{gal} / \mathrm{min}$; well-head pressure was $47 \mathrm{lb} / \mathrm{in}^{2}$ at this rate. At $884 \mathrm{~min}$, injęction rate was increased to about 320 gal/min; well-head pressure was $69 \mathrm{lb} / \mathrm{in}$. Injection ceased at $955 \mathrm{~min}$, and bottom-hole pressure recovery was observed for $195 \mathrm{~min}$.

The change in bottom-hole pressure during the test is shown in figure 5 . Upon gtarting injection, pressure oscillated, dropping to a minimum of 1,931 $1 \mathrm{~b} / \mathrm{in}^{2}$ after $1.8 \mathrm{~min}$, then rising to a maximum of $1,993 \mathrm{lb} / \mathrm{in}^{2}$ after $11 \mathrm{~min}$ of injection. Pressure dẹclined to $1,965 \mathrm{lb} / \mathrm{in}^{2}$ at $28 \mathrm{~min}$, then gradually increased to $1,970 \mathrm{lb} / \mathrm{in}^{2}$ until the injection rate was increased to $285 \mathrm{gal} / \mathrm{min}$. The pressure then rose to $1,974 \mathrm{lb} / \mathrm{in}^{2}$ and the injection rate was again increased. Immediately prior to the time injection stopped, pressure was 1,975 $\mathrm{lb} / \mathrm{in}^{2}$ at an injection rate of $320 \mathrm{gal} / \mathrm{min}$.

Figure 5 shows that oscillation in pressure again occurred when injection stopped. Pressure dropped to $1,959 \mathrm{lb} / \mathrm{in}^{2}$ at $7 \mathrm{~min}$ of recovery, then rose to $1,966 \mathrm{lb} / \mathrm{in}_{2}$ at $29 \mathrm{~min}$. Final pressure reading before removing the gage was $1,965 \mathrm{lb} / \mathrm{in}^{2}$.

Following the bottom-hole pressure test, the plant resumed normal injection operations from April 5 to April 11, 1975. Injection was stopped at 1:30 p.m. on April 11. Three days later, at 11:00 a.m. on April 14, the injection test was begun with observations made at the satellite well. Waste was injected at 


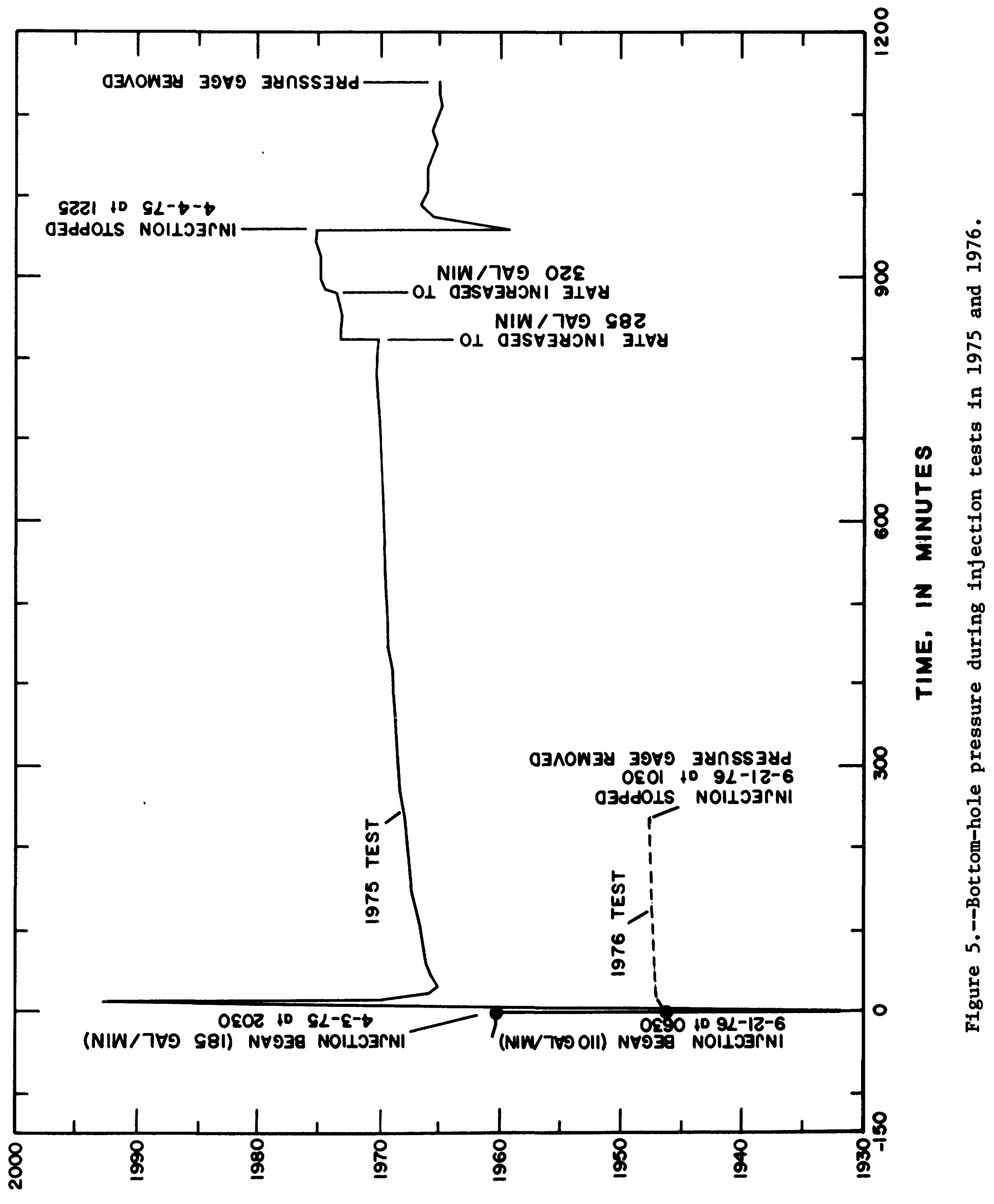

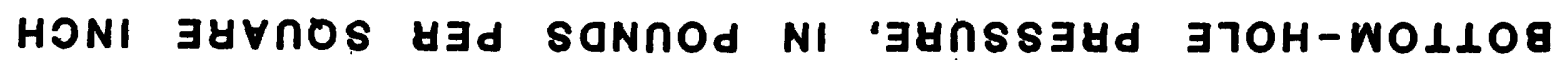


the injection well at a rate of $230 \mathrm{gal} / \mathrm{min}$ and water-level changes were observed in the satellite monitor well. Injection continued until April 21 at 10:00 a.m., a total of 6.96 days, or 10,020 min. Recovery was measured at the satellite monitor well for 300 min before normal plant operations resumed.

As a check on the early response of the injection well and satellite monitor well, an additional short test was run in September 1976. Prior to this test, the injection tube and pipes leading to the injection well were filled with injection fluid to minimize surging. The well was shut in and bottom-hole pressure allowed to stabilize at $1,947 \mathrm{lb} / \mathrm{in}^{2}$. Starting at 6:30 a.m. on September 21, 1976, waste effluent diluted with pond water (specific gravity 1.004) was injected at a rate of $110 \mathrm{gal} / \mathrm{min}$ for 4 hours, or $240 \mathrm{~min}$. Bottomhole pressure in the injection well and water levels in the satellite monitor well were observed during injection. Bottom-hole pressure changes are shown in figure 5.

Factors That Complicate the Interpretation of

Water-Level Data at the Kaiser Site

Three principal factors complicate the interpretation of the water-level data at the Kaiser site. The importance of each of these factors cannot be quantitatively evaluated. However, they can be qualitatively discussed and thus used as a guide to identify water levels that would be most reliable for aquifer-test interpretation.

The factors that may distort the water-level data at the satellite monitor well are:

1. Pressure oscillations at start of injection;

2. Permeability differences in the injection zone; and

3. Background water-level trend removal.

Figure 5 shows pressure oscillations at the beginning of the bottom-hole pressure test in 1975. The initial $60 \mathrm{~min}$ (approximate duration of surge plus recovery) of observed water-level changes in the satellite well may be unreliable because of these oscillations, even though there is little evidence that the oscillations actually propagated through the aquifer as far as the observation well.

The injection zone has vertical differences in permeability and presumably, therefore, in hydraulic diffusivity. Because of this, at the beginning of injection or a change in injection rate, water-level transients will propagate away from the injection well at different rates in the upper and lower parts of the injection zone. The most rapidly moving transients will tend to initiate water-level changes in a distant observation well sooner than would be observed if changes propagated homogeneously at the rate dictated by the total transmissivity and storage characteristics of the injection zone. On the other hand, changes reflecting the total transmissivity are well represented by the later parts of the water-level change curve (fig. 6), after the initial transients have propagated beyond the observation well. The time at which the effects of early transients become insignificant may not be readily definable by simple inspection of a data plot. However, at $200 \mathrm{~min}$ both corrected and uncorrected 


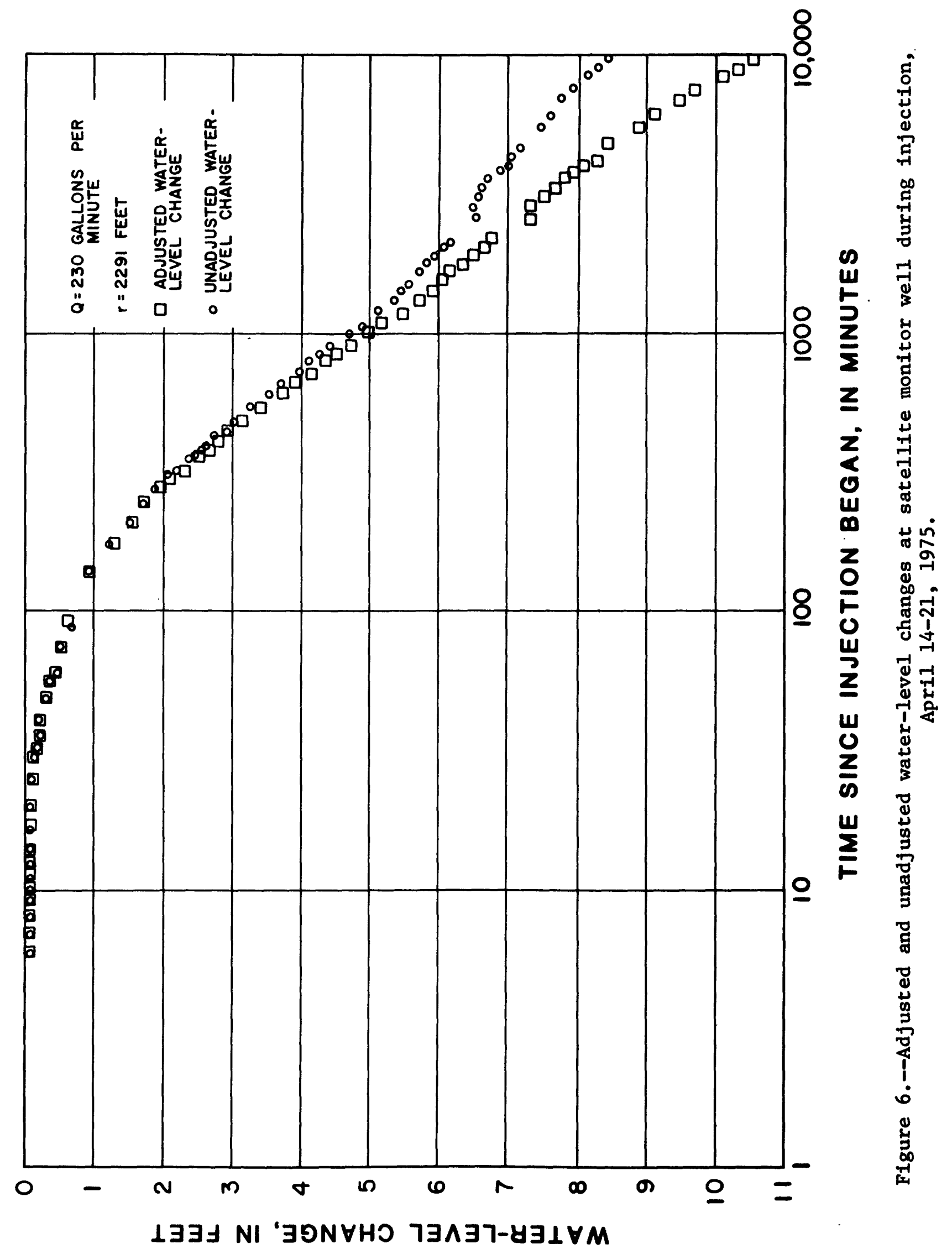


water-level changes are approaching a constant log-time rate of buildup (fig. 6). This suggests that water-level changes are starting to reflect the total transmissivity and that changes at times greater than 200 min should be emphasized for aquifer-test interpretation.

For the 1975 monitor-well test, water-level changes in the monitor well were adjusted for barometric-pressure fluctuations and changes due to a continuation of a previous downward water-level trend. Only minor barometric fluctuations occurred during the test; maximum correction to the measured water level, using an assumed barometric efficiency of 0.7 , was $-0.11 \mathrm{ft}$.

Estimated background water-level changes have to be considered as uncertain during the 1975 monitor-well test because water-level trend projections were based on only about 2 days of prior data. Maximum correction for previous trend was 2.08 feet. In figure 6 , adjusted and unadjusted water-level changes in the monitor well deviate significantly from each other after about 1,000 min. Waterlevel changes prior to 1,000 min would be least affected by trend removal and should be emphasized for aquifer test interpretation.

Estimated Injection Zone Hydraulic Characteristics

Test data most suitable for interpretation of injection-zone hydraulic characteristics are from the 1975 test with observations made in the satellite we11. All other tests were considered unsultable for determining injectionzone characteristics because of their short duration. However, only a small part of the 1975 test data--200 to 1,000 min--can be considered as reliable. Therefore, the calculated hydraulic characteristics have to be viewed as physically plausible estimates rather than exact values.

The analytic model chosen as most appropriate to use for the interpretation of the test data was the mathematical solution for short time derived by Hantush (1960) for a well in a leaky aquifer bounded by semipervious and compressible confining layers. This model was chosen because of the probable importance of storage in the confining layers as suggested by the large difference in probable thickness, and thus storage, between the injection zone and the upper and lower confining beds.

Transmissivity and storage coefficient of the injection zone and the product of hydraulic conductivity and specific storage of the confining beds were interpreted from the test data using the Hantush type curve method (fig. 7). A range of estimated values for each of these parameters is shown below. A range was determined because a representative value for each parameter could not be interpreted from the data. Specific storage values in the following table may appear to be low but because of the injection zone's depth of burial, they are physically plausible.

Transmissivity ( $\mathrm{T})$--

Storage coefficient (S) --

Specific storage $\left(\mathrm{s}_{S}\right)--$

Confining bed hydraulic conductivity times specific storage $\left(K^{\prime} S^{\prime}{ }_{S}\right)--$
700 to $1,000 \mathrm{ft}^{2} / \mathrm{d}$

$4 \times 10^{-5}$ to $6 \times 10^{-5}$

$9.7 \times 10^{-8}$ to $1.5 \times 10^{-7} \mathrm{ft}^{-1}$

$1.4 \times 10^{-9}$ to $7.2 \times 10^{-9} 1 / \mathrm{d}$ 


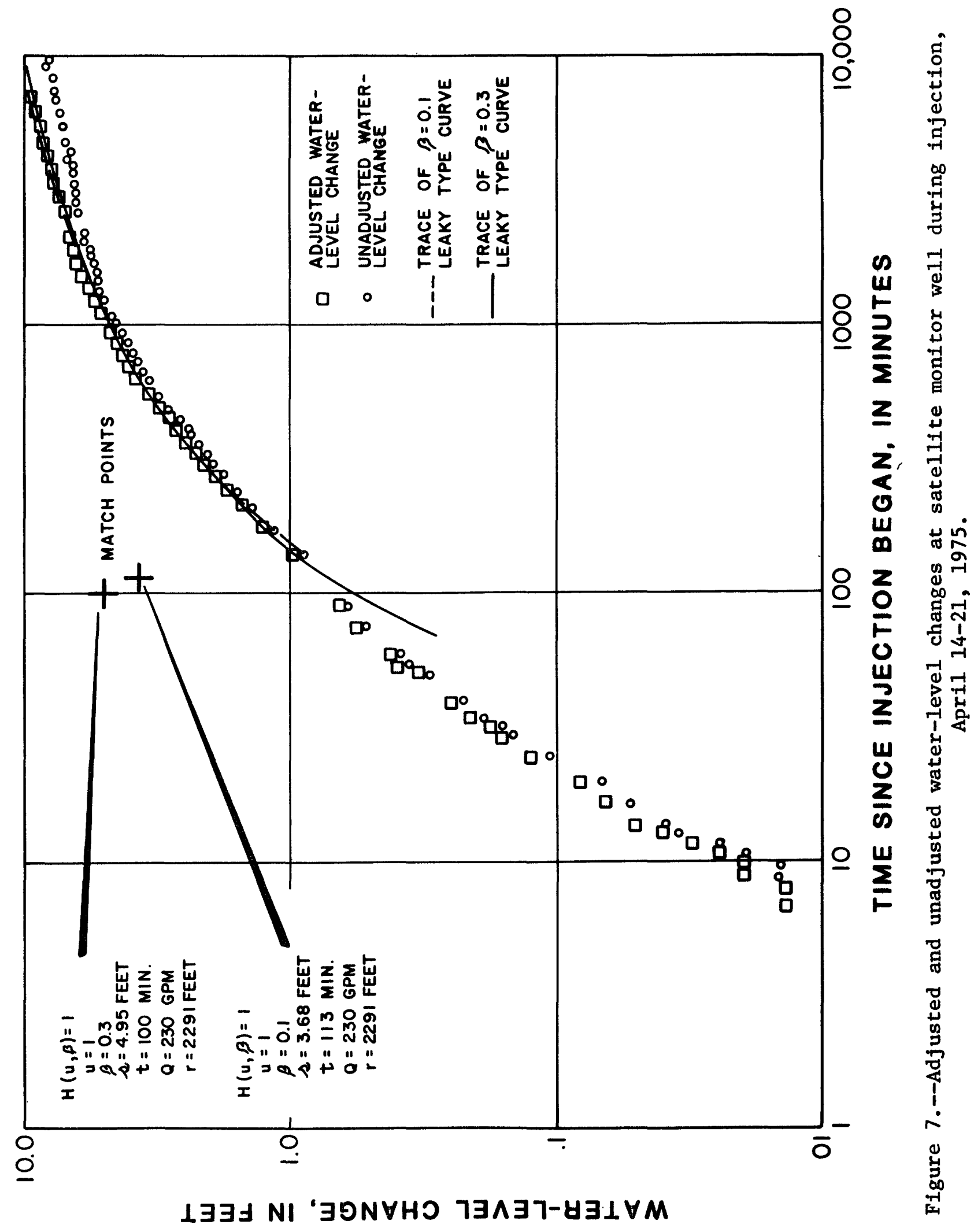


Vertical hydraulic conductivity of the confining beds was calculated by assuming that the estimated specific storage of the injection zone could be applied to the confining beds. Given the similar lithology, depth of burial, and age of the confining beds, this assumption is reasonable. Calculated hydraulic conductivities range from 0.01 to $0.08 \mathrm{ft} / \mathrm{d}$ and compare favorably with hydraulic conductivities of sidewall cores ranging from 0.02 to $0.12 \mathrm{ft} / \mathrm{d}$ reported by Wilson and others (1973) for the lower confining bed. Laboratory analyses of permeability, corrected for fluid viscosity and density, of sidewall cores taken from the upper confining bed during drilling of the satellite monitor well range from 0.6 to 1.6 millidarcies (unpublished data, Kaiser Aluminum and Chemical Corp.). Hydraulic conductivities based on these data range from 0.002 to $0.005 \mathrm{ft} / \mathrm{d}$ and are much smaller than those from the lower confining bed and those calculated from the test results, discussed above.

\section{DISCUSSION}

The 1975 injection test provided more reliable indications of injectionzone characteristics than did the 1972 well-head pressure test. Based on the 1975 test, transmissjivity of the injection zone probably is within the range from 700 tg $1,000 \mathrm{ft} / \mathrm{d}$, and storage coefficient is probably within the range
from $4 \times 10^{-5}$ to $6 \times 10^{-5}$.

The 1975 test results also provided data that can be interpreted to indicate leakage from the injection zone. However, the confining bed accepting most of the leakage could not be deduced directly from the test results. Geophysical logs and laboratory analyses of cores suggest that the lower confining bed is more permeable than the upper confining bed. Therefore, it is reasonable to hypothesize that the lower confining bed probably accepted most of the leakage during the 1975 injection test.

\section{CONCLUSIONS}

Hydrogeologic interpretations and results of injection tests conducted at the Kaiser Aluminum and Chemical plant have provided additional understanding of the uncertainties in evaluating the hydraulic characteristics of a deep injection zone where less dense acidic wastes are injected into carbonate rocks containing more dense formation water. Despite the uncertainties, results suggest that the injection zone has relatively low transmissivity and is, therefore, best suited for injection only at relatively low rates, as is done at the Kaiser plant. In addition, interpretations and results suggest that leakage of neutralized waste is directed principally downward into underlying beds. Thus, the alternating beds of anhydrite and dolomite overlying the injection zone have a low hydraulic conductivity and are probably effective in retarding significant vertical movement of the neutralized waste. Finally, long-term use of the injection zone probably depends more on the rate and direction of dissolution of beds in the vicinity of the injection well than upon the hydraulic behavior of neutralized waste at a distance from the well. 
Hantush, M. S., 1960, Modification of the theory of leaky aquifers: Journal of Geophysical Research v. 65, p. 3713-3725.

Shannon and Wilson, Inc., 1976, Evaluation of cavity development and stability, disposal well no. 1, Mulberry, Florida: Consultant's report for Kaiser Aluminum and Chemical Corporation, Oakland, California.

1977, Review and evaluation of monitoring data through January 1977 and details of cavity stability considerations, disposal well no. 1, Mulberry, Florida: Consultant's report for Kaiser Aluminum and Chemical Corporation, Oakland, California.

Wilson, W. E., 1977, Hydrologic data for a subsurface waste-injection site at Mulberry, Florida, 1972-76: U.S. Geological Survey Open-File Report $77-511,24 \mathrm{p}$.

Wilson, W. E., Rosenshein, J. S., and Hunn, J. D., 1973, Hydrologic evaluation of industrial-waste injection at Mulberry, Florida: Underground Waste Management and Artificial Recharge, v. 1, 1973, p. 552-564. 
